\title{
Mystery Case: Spinal tuberculosis masquerading lung malignancy
}

Ravindra Kumar Garg, DM, Manan Mayur Mehta, MD, Riddhi Jaiswal, MD, Hardeep Singh Malhotra, DM, Imran Rizvi, DM, and Shweta Pandey, DM

Neurology ${ }^{\circledR}$ 2018;91:632-633. doi:10.1212/WNL.0000000000006248

A 32-year-old woman presented with backache of 4 months' duration. She also complained of cough, anorexia, and some weight loss. She had a local tenderness at T6-T7 vertebrae. CNS was normal. A chest X-ray revealed a left lower lobe lung lesion (figure, A). CT thorax and MRI dorsal spine revealed left lung consolidation, pleural collection, T6 vertebral wedge collapse, and paravertebral collection (figure, B-E). Differential diagnoses included spinal tuberculosis (Pott disease) vs metastatis. ${ }^{1}$ Pleural biopsy revealed a tuberculous granulomatous lesion (figure, F). She was given antituberculosis drugs. After 1 month, remarkable pain relief was noted.

\section{Author contributions}

Ravindra Kumar Garg: concept, drafting manuscript, revision, analysis. Manan Mayur Mehta: drafting manuscript, revision, analysis. Riddhi Jaiswal: concept, drafting manuscript, revision, analysis. Hardeep Singh Malhotra: concept, drafting manuscript, analysis. Imran Rizvi: drafting manuscript, revision, analysis. Shweta Pandey: drafting manuscript, revision, analysis.

\author{
Correspondence \\ Dr. Garg \\ garg50@yahoo.com
}

\section{MORE ONLINE}

Survey and results

NPub.org/mc9113

Figure Chest X-ray shows a lung lesion, neuroimaging suggests spinal tuberculosis (Pott disease), and pleural biopsy confirms tuberculosis

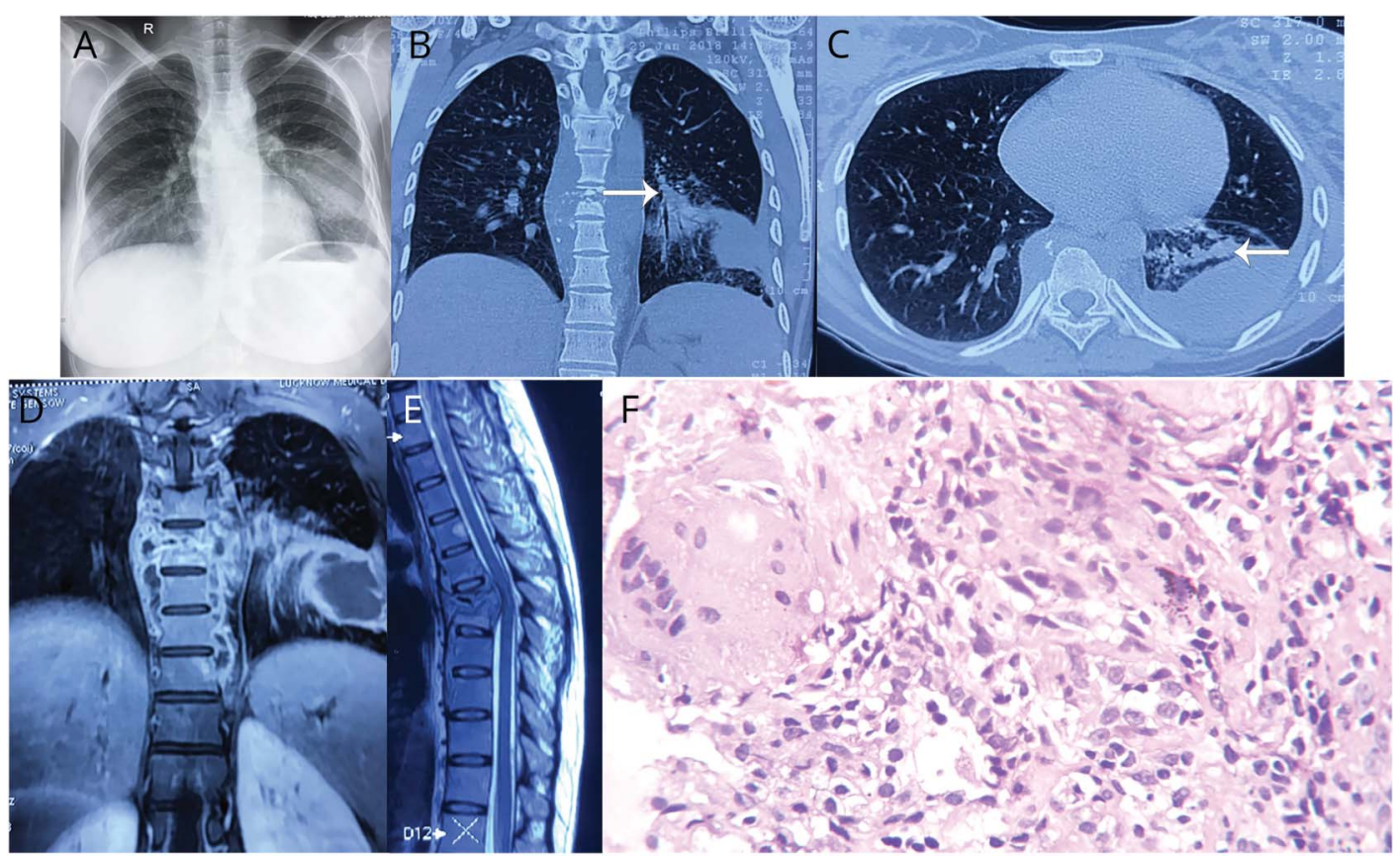

(A) Chest X-ray shows left lower lung opacity. (B, C) CT thorax shows a centrilobular nodule (tree in bud appearance). (C-E) MRI shows collapse of T6 and T7 vertebrae with paravertebral collection. (F) Pleural biopsy shows tuberculous granuloma with multinucleated giant cells, epithelioid cell, and caseation. Acidfast bacilli staining was negative. Magnification is $\times 400$.

From the Department of Neurology (R.K.G., M.M.M., H.S.M., I.R., S.P.) and Department of Pathology (R.J.), King George's Medical University, U.P., Lucknow, India. Go to Neurology.org/N for full disclosures. Funding information and disclosures deemed relevant by the authors, if any, are provided at the end of the article. 


\section{Study funding}

No targeted funding reported.

\section{Disclosure}

R. Garg receives regular honorarium for writing clinical summaries for Med Link Neurology, Med Link Corporation, San Diego. M. Mehta, R. Jaiswal, H. Malhotra, I. Rizvi, and S. Pandey report no disclosures relevant to the manuscript. Go to Neurology.org/ $\mathrm{N}$ for full disclosures.

\section{Reference}

1. Ringshausen FC, Tannapfel A, Nicolas V, et al. A fatal case of spinal tuberculosis mistaken for metastatic lung cancer: recalling ancient Pott's disease. Ann Clin Microbiol Antimicrob 2009;8:32.

\section{Mystery Case responses}

The Mystery Case series was initiated by the Neurology ${ }^{\circledR}$ Resident \& Fellow Section to develop the clinical reasoning skills of trainees. Residency programs, medical student preceptors, and individuals were invited to use this Mystery Case as an educational tool. Responses to multiple choice questions formulated using this case were solicited through a group email sent to the American Academy of Neurology Consortium of Neurology Residents and Fellows and through social media. We received 230 responses. The majority of respondents (63\%) had just been in practice for 1-4 years; $55 \%$ were residents or fellows while $31 \%$ were faculty/board-certified physicians; the remainder were medical students or advanced practice providers. A total of $91 \%$ resided outside the United States. A wide range of practice settings was represented.

When presented with a brief clinical vignette about this patient (described in our online case as having recently immigrated from India and presenting with backache, cough, anorexia, weight loss, and local tenderness at $\mathrm{T} 6 / 7$ on examination), and asked what 2 investigations they would order, $72 \%$ of respondents appropriately selected MRI thoracic spine. Recognizing the importance of investigating the respiratory complaints, 30\% also selected CT chest while 36\% selected chest X-ray; both are appropriate choices although
CT chest would be more definitive. Upon then being presented the CT chest and MRI T-spine, $81 \%$ correctly identified the T6 vertebral wedge collapse and $70 \%$ identified the left lung consolidation. Forty-four percent also correctly identified the T6 paravertebral collection. Thirty-one percent also identified a left pleural collection. Twenty percent incorrectly reported a T6 cord signal change.

Upon then being asked to select their top 2 differential diagnoses, the 2 most popular and correct choices were Pott disease (72\%) and metastasis (57\%). Other favored choices included osteosarcoma (17\%), which can metastasize to the lungs but more typically with multiple smaller nodules rather than with a single lung consolidation, ${ }^{1}$ and Paget disease (8\%), a condition involving cellular remodeling and bony deformity. ${ }^{2}$ Respondents were then presented with the patient's pleural biopsy result and asked for their final diagnosis; interestingly this resulted in fewer people selecting the correct answer of Pott disease (58\%), with the remainder spread across different options including metastasis (9\%). However, the biopsy shows a tuberculous granuloma with multinucleated giant cells, in keeping with Pott disease.

Tuberculosis continues to be an important worldwide public health problem, including in North America and Europe, especially among deprived socioeconomic groups, older or immunocompromised patients, drug-resistant cases, as well as immigrant and indigenous (North American) populations. ${ }^{3}$ The spine is the most frequent location of musculoskeletal tuberculosis.

Aravind Ganesh, MD

Department of Clinical Neurosciences, University of Calgary, Canada

\section{References}

1. Staddon AP, Lackman R, Robinson K, Shrager JB, Warhol M. Osteogenic sarcoma presenting with lung metastasis. Oncologist 2002;7:144-153.

2. Paul Tuck S, Layfield R, Walker J, Mekkayil B, Francis R. Adult Paget's disease of bone: a review. Rheumatology 2017;56:2050-2059.

3. Rivas-Garcia A, Sarria-Estrada S, Torrents-Odin C, Casas-Gomila L, Franquet E. Imaging findings of Pott's disease. Eur Spine J 2013;22(suppl 4):567-578.

\section{Neurology ${ }^{\circledR}$ Online CME Program}

Earn CME while reading Neurology. This program is available only to online Neurology subscribers. Read the articles marked CME, go to Neurology.org, and click on CME. This will provide all of the information necessary to get started. The American Academy of Neurology (AAN) is accredited by the Accreditation Council for Continuing Medical Education (ACCME) to sponsor continuing medical education for physicians. Neurology is planned and produced in accordance with the ACCME Essentials. For more information, contact AAN Member Services at 800-879-1960. 


\section{Neurology}

\section{Mystery Case: Spinal tuberculosis masquerading lung malignancy \\ Ravindra Kumar Garg, Manan Mayur Mehta, Riddhi Jaiswal, et al. \\ Neurology 2018;91;632-633 \\ DOI 10.1212/WNL.0000000000006248}

This information is current as of September 24, 2018

$\begin{array}{ll}\begin{array}{l}\text { Updated Information \& } \\ \text { Services }\end{array} & \begin{array}{l}\text { including high resolution figures, can be found at: } \\ \text { http://n.neurology.org/content/91/13/632.full }\end{array} \\ \text { References } & \text { This article cites } 4 \text { articles, } 0 \text { of which you can access for free at: } \\ \text { http://n.neurology.org/content/91/13/632.full\#ref-list-1 } & \\ \text { This article, along with others on similar topics, appears in the } \\ \text { following collection(s): } \\ \text { Abscess } \\ \text { http://n.neurology.org/cgi/collection/abscess } \\ \text { All Spinal Cord } \\ \text { http://n.neurology.org/cgi/collection/all_spinal_cord } \\ \text { Bacterial infections } \\ \text { http://n.neurology.org/cgi/collection/bacterial_infections } \\ \text { Information about reproducing this article in parts (figures,tables) or in } \\ \text { its entirety can be found online at: } \\ \text { http://www.neurology.org/about/about_the_journal\#permissions } \\ \text { Information about ordering reprints can be found online: } \\ \text { http://n.neurology.org/subscribers/advertise }\end{array}$

Neurology ${ }^{\circledR}$ is the official journal of the American Academy of Neurology. Published continuously since 1951, it is now a weekly with 48 issues per year. Copyright () 2018 American Academy of Neurology. All rights reserved. Print ISSN: 0028-3878. Online ISSN: 1526-632X.

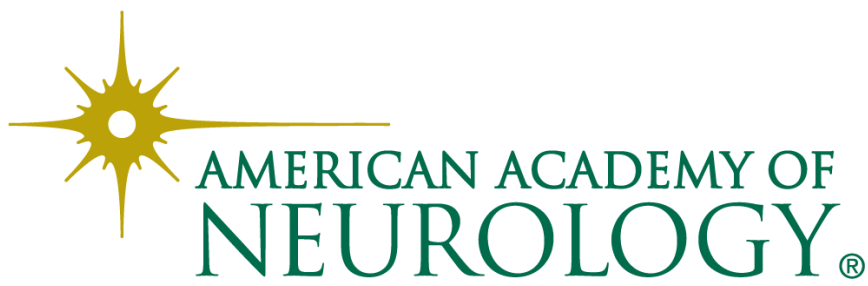

